
\title{
$\begin{array}{ll}\text { Research Square } & \begin{array}{l}\text { Preprints are preliminary reports that have not undergone peer review. } \\ \text { They should not be considered conclusive, used to inform clinical practice, } \\ \text { or referenced by the media as validated information. }\end{array}\end{array}$
}

\section{The Influence of Concrete and Urban Water Quality On The Growth of An Invasive Weed (Salix Spp.) in One of Australia's Most Endangered Aquatic Environments.}

\author{
Katherine Purdy \\ Western Sydney University \\ Jason K Reynolds \\ Western Sydney University \\ lan Alexander Wright ( $\sim$ i.wright@uws.edu.au ) \\ Western Sydney University https://orcid.org/0000-0002-8567-4797
}

\section{Research Article}

Keywords: urban stream syndrome, urban geochemistry, invasive weeds, concrete materials, barium and strontium

Posted Date: November 10th, 2021

DOl: https://doi.org/10.21203/rs.3.rs-1050910/v1

License: (c) (i) This work is licensed under a Creative Commons Attribution 4.0 International License. Read Full License 


\section{Abstract}

Riparian vegetation along urban streams and wetlands is frequently dominated by invasive weeds. Elevated nitrogen and phosphorous in urban waters and soils are well-known to encourage invasive urban weeds, but this research demonstrates that other urban geochemical contaminants may also be influential. Previous studies have demonstrated that the dissolution of urban concrete is a poorly recognised source of modified water and soil geochemistry, which may enhance the growth of some invasive weeds. This study investigated the relationship between urban water quality and the growth of an invasive urban riparian weed, willow (Salix spp.) to examine the contribution of concrete materials. The study used water from a wetland in the Greater Blue Mountains World Heritage Area. These wetlands have a unique biodiversity but are fragile and susceptible to degradation from human activity. Many are in urban catchments and are frequently dominated by invasive weeds, including Salix spp. In this study, willow cuttings were grown in a laboratory using four water treatments: pristine, urban, and pristine water exposed to two different concrete materials. The urban and concrete water treatments had higher $\mathrm{pH}$, salinity, calcium, potassium, and higher concentration of several metals and were associated with increased growth of Salix spp. We suggest that the modification of urban water and riparian soil chemistry by urban concrete materials may contribute to the success of invasive species in urban wetlands and riparian zones. Some metals (barium, strontium) were present in urban water and in pristine water exposed to concrete and bioaccumulated in plant tissue.

\section{Introduction}

Riparian zones alongside streams in urbanised areas frequently exhibit modified vegetation communities when compared to non-urbanised areas (Ehrenfeld and Schneider 1991; Leishman, Hughes and Gore 2004). Urban streambanks are often dominated by invasive weed species, with few or no native species present (Cockel and Gurnell 2012; Dean and Tippler 2016; King and Buckney 2002; Tippler, Wright and Hanlon 2012). Such degradation in urban riparian vegetation communities is considered one of the key symptoms of the urban stream syndrome (USS) (Paul and Meyer 2001; Walsh et al. 2005), which was also found to operate in upland urban wetlands in the Blue Mountains region of NSW, Australia (Belmer, Tippler and Wright 2018; Belmer, Wright and Tippler 2015).

Riparian vegetation plays a key role in stabilising, binding and reinforcing banks (Gurnell, Lee and Souch 2007), as well as regulating stream temperature, trapping and filtering nutrients and pollutants, and contributing organic matter to streams (Wenger et al. 2009). Thus, changes in riparian vegetation communities can have cascading ecosystem effects and can result in erosion, unstable channels, and increased influx of pollutants to the waterway (Gurnell, Lee and Souch 2007). Dominance of invasive plant species in riparian vegetation can also have detrimental impacts through reduction of habitat value for endemic biota and particularly for endangered fauna species (Samways and Taylor 2004).

Many factors likely contribute to the success of non-native species in urban waterways. Exotic species are generally able to invade urban stream ecosystems due to a series of hydrological, physical, and chemical changes associated with USS (Paul and Meyer 2001). An important factor is proximity to urban areas, which allows propagules to enter the stream from nearby human habitation (King and Buckney 2000). Urban areas also provide numerous convenient transport paths for weed propagules, including waterways, vehicles, humans, and domestic animals (Akasaka, Osawa and Ikegami 2015). Thus, exotic species present in populated centres potentially have several mechanisms available to spread to nearby ecosystems. However, the success of exotic plant species in urban riparian zones is also strongly influenced by the chemical differences observed in water and soil between urban and non-urban areas (Leishman and Thomson 2005).

Urban waterways are generally chemically degraded compared to waterways in pristine non-urban areas (Meyer, Paul and Taulbee 2005; Paul and Meyer 2001; Walsh et al. 2005). One of the key symptoms of USS are higher concentrations of phosphorous and nitrogen (Paul and Meyer 2001; Tippler, Wright and Hanlon 2012). Urban waterways also tend towards higher $\mathrm{pH}$ values and higher electrical conductivity (EC) and exhibit ionic modification such as dominance by sodium, 
chloride, potassium, bicarbonate, and calcium ions (Connor et al. 2014; Conway 2007; Kaushal et al. 2005; Tippler, Wright and Hanlon 2012; Wenger et al. 2009).

Similarly, urban soils exhibit a variety of chemical differences when compared to soil in more pristine areas. Multiple studies have noted that areas with higher proportions of invasive species had soil that was higher in $\mathrm{pH}$ and salinity as well as highly enriched with potassium, phosphorous, and calcium (Grella, Renshaw and Wright 2018; Park et al. 2010; Shaw and Reeve 2008). Nutrients such as nitrogen and phosphorous are linked with increased weed growth and higher concentrations of both are associated with riparian weed invasions (Leishman, Hughes and Gore 2004; Leishman and Thomson 2005). Modified urban riparian soil chemistry may inhibit native species that are less tolerant to these conditions and encourage the establishment of exotic species that are more adapted to these urban environments (King and Buckney 2000). This idea is supported by Leishman and Thomson (2005), who observed that native plant seedlings were killed by elevated soil phosphorus concentrations.

Urban water and soils also commonly contain a wide range of pollutants including pesticides and heavy metals (Paul and Meyer 2001). This has been termed urban geochemistry and common metals recorded in urban streams at elevated levels include cadmium, chromium, copper, lead, and zinc (Wenger et al. 2009). Depending on their bioavailability, heavy metals can transfer further into the ecosystem and can have a variety of effects on plant growth and processes (Ugulu 2015). While many heavy metals are important in plant and animal biochemical and physiological functions, they can also be toxic at higher concentrations (Tchounwou et al. 2012). For example, chromium toxicity in plants has been reported (Oliveira 2012), and copper can be toxic to aquatic invertebrates (Tchounwou et al. 2012). Heavy metals can also affect a variety of plant processes, including tissue development, germination, and photosynthesis (Oliveira 2012).

There is growing recognition that urban geochemistry can be associated with weathering of urban concrete materials (Kaushal et al. 2013; Tippler, Wright and Hanlon 2012). Recirculation of non-urban water through pipes composed of concrete materials has shown that exposing water to typical urban concrete materials can result in a rapid increase in water $\mathrm{pH}$, salinity, calcium, potassium, and bicarbonate (Davies et al. 2010; Grella et al. 2014). Recycled concrete aggregates (RCAs) are a widely used recycled building material that are often used in urban construction and drainage settings. When RCAs have been exposed to water in laboratory settings, experimental results have documented rapidly increasing $\mathrm{pH}$ and the release of a suite of ionic and metallic elements, sometimes rapidly reaching ecologically hazardous concentrations (Purdy, Reynolds and Wright 2020; Wright et al. 2018).

Blue Mountains Uplands Swamps (BMUS) are fragile and ecologically significant plant communities that are known to be highly vulnerable to physical, chemical, and biological impacts associated with urban development (Benson and Baird 2012; Fryirs, Freidman and Kohlhagen 2012; Gorissen et al. 2015). BMUS are peat swamps that have formed in sandstone geology in the higher elevations of the Blue Mountains region of south eastern Australia. They are listed as endangered ecological communities under the Environment Protection and Biodiversity Conservation Act 1999 (Commonwealth) and Biodiversity Conservation Act 2016 (NSW) (Gorissen et al. 2015). They also contain many plant and animal species of conservation significance, including the endangered Blue Mountains Water Skink (Eulamprus leuraensis), which is exclusively dependent on BMUS (Department of the Environment and Energy (DEE) 2019; Gorissen, Greenlees and Shine 2017; Hensen and Mahony 2010). About one third of BMUS are located within urban catchments and have been affected by invasive weed infestations (Hensen and Mahony 2010). The NSW Scientific Committee recommended declaration of BMUS as a vulnerable ecological community that is facing a high risk of extinction (NSW Scientific Committee 2007). This declaration also noted that there were nine problematic weeds in BMUS, including willows (Salix spp.).

Previous studies have reported that water quality in naturally vegetated non-urban BMUS is acidic (mean pH<5) and dilute $(<41 \mu \mathrm{S} / \mathrm{cm}$ ), with a very low buffering capacity and undetectable concentrations of calcium and magnesium (Belmer, Wright and Tippler 2015; Carroll, Reynolds and Wright 2020). In contrast, urban BMUS have higher pH, EC, and increased concentrations of all major ions (Belmer, Wright and Tippler 2015; Carroll, Reynolds and Wright 2020). Carroll, Reynolds 
and Wright (2020) investigated the concentration of 17 metals in urban and non-urban BMUS and found that two metals (barium and strontium) were present at much higher concentrations in water and sediment of urban BMUS. The difference between urban and non-urban BMUS was largest for strontium. It was measured in water in urban BMUS (mean $45 \mu \mathrm{g} / \mathrm{L}$ ), which was more than 30 times greater than non-urban BMUS (mean $1.4 \mu \mathrm{g} / \mathrm{L}$ ) (Carroll, Reynolds and Wright 2020). Both Carroll, Reynolds and Wright (2020) and Belmer, Wright and Tippler (2015) supported the hypothesis that the geochemical pattern of contamination in urban BMUS appears to be influenced by dissolution of urban concrete materials (Davies et al. 2010; Kaushal et al. 2013; Tippler et al. 2014; Wright et al. 2011).

Given that concrete is becoming more widely recognised as a source of geochemical modification in urban waterways (Davies et al. 2010; Grella et al. 2014; Wright et al. 2011), it is important to investigate how these changes in water and soil chemistry in urban waterways are likely to affect riparian vegetation. Urban concrete infrastructure is being increasingly recognised as a source of metal contamination (Purdy and Wright 2019; Rahman et al. 2014) and this has many implications for ecosystems, including potentially affecting plant processes by contributing metals to urban water and soils (Ugulu 2015). Plants accumulate pollutants in their tissues and plants in urban areas near high traffic streets and residential areas frequently have higher concentrations of metals in their tissues (Buszewski et al. 2000). Metals are also frequently present in urban streams (Meyer, Paul and Taulbee 2005; Wenger et al. 2009) and the effects of having such metals and modified ionic composition in an urban riparian ecosystem is poorly understood. Further investigation is required to determine whether heavy metals present in stream water become bioavailable and are taken up into plant tissue, and thus whether they may influence riparian vegetation. Additionally, it is hypothesised that, if heavy metals are bioavailable, they may travel further into the food chain and ecosystem and could be used as tracers or markers to measure the level of urban concrete exposure in ecosystems.

This study aimed to:

1. Explore how urban water and pristine water exposed to concrete influence the growth and development of a known invasive riparian weed species in the Blue Mountains region, Salix spp.

2. Investigate whether metals leached into water via concrete exposure are taken-up by Salix spp. into its tissue and whether they can be used as metal 'tracers' for concrete exposure.

\section{Materials And Methods}

\subsection{Water treatment chemical differences}

Water chemistry differed between the four different water treatments at the outset of this study (Purdy et al. 2020; Table 1). The four treatments used water obtained from two different BMUS wetlands. One treatment was sourced from surface water from a BMUS in a catchment that was partly occupied by urban land. This was the Bullaburra BMUS, which had been affected by recent modifications to the local stormwater system, built to drain a nearby local highway (Belmer, Wright and Tippler 2015). This water was the urban treatment.

Water was also collected from the surface water of a reference BMUS in a naturally vegetated area, managed and protected as part of Greater Blue Mountains World Heritage Area (Belmer, Wright and Tippler 2015). This near-undisturbed BMUS, near Mount Hay, had no urban development in its catchment (Belmer, Wright and Tippler 2015). This water was used as the pristine reference treatment, with additional water collected from this location as the source water for exposure to different forms of concrete materials (Purdy, Reynolds and Wright 2020).

Two sub-samples of additional pristine reference water were exposed to different concrete materials according to detailed methods available in an associated study (Purdy, Reynolds and Wright 2020), which produced two of the water treatments used in this current study. Purdy, Reynolds and Wright (2020) produced these water treatments by recirculating pristine 
reference BMUS water through two different types of concrete materials for 60 minutes. One was an unused steelreinforced concrete water pipe and produced concrete whole pipe water treatment. The other produced RCA water by recirculating pristine reference water through a PVC gutter containing small $(<20 \mathrm{~mm})$ concrete fragments called recycled concrete aggregate (RCA) materials (DECCW (NSW Department of Environment 2010). Concrete pipes are commonly used in global urban drainage systems (Davies et al. 2010; Wright et al. 2011) and RCA materials are widely used world-wide as a substitute for gravel (Rahman et al. 2014). Both concrete products are commonly used as drainage materials in Blue Mountains urban areas (personal observation). Previous research has demonstrated that exposure of RCA fragments in water can rapidly modify water quality (Purdy, Reynolds and Wright 2020; Wright et al. 2018).

The RCA water treatment had the highest mean values for ten of the 13 water chemistry attributes that were measured for all water treatments prior to the growth experiment beginning (Table 1). The pristine reference water only had detectable results for seven of the 13 water quality attributes (Table 1). The four water treatments all had different $\mathrm{pH}$ and $\mathrm{EC}$ values (Table 1). The pristine reference water had lowest mean pH, at 4.89, while the RCA water had the highest mean pH at 8.91. Similarly, pristine reference water was the most dilute (mean $27.88 \mu \mathrm{S} / \mathrm{cm}$ ), whilst the mean EC of RCA water was more than 11 times higher and was highest of the treatments in this study $(340.0 \mu \mathrm{S} / \mathrm{cm})$.

Differences in the concentration of major cations were observed across the four different treatments prior to the start of the growth experiment (Table 1) (Purdy, Reynolds and Wright 2020). The only cation detected in pristine reference water was sodium (mean $3.7 \mathrm{mg} / \mathrm{L}$ ). The highest sodium concentration was found in RCA water (mean $21.5 \mathrm{mg} / \mathrm{L}$ ). Calcium was the dominant cation in RCA water (mean $34.6 \mathrm{mg} / \mathrm{L}$ ) and was lower in urban water (mean $12.33 \mathrm{mg} / \mathrm{L}$ ) and concrete pipe water (mean $8.49 \mathrm{mg} / \mathrm{L}$ ). Potassium was not detected in reference water but was measured in urban water (mean $2.04 \mathrm{mg} / \mathrm{L}$ ), in concrete pipe water (mean $2.93 \mathrm{mg} / \mathrm{L}$ ) and was highest in RCA water (13.7 mg/L). Magnesium was not found at detectable concentrations in pristine reference water or concrete pipe water but was in urban water (mean 1.34 $\mathrm{mg} / \mathrm{L}$ ) and RCA water (mean $0.97 \mathrm{mg} / \mathrm{L}$ ).

Water samples were also tested for seven metals prior to the start of the growth experiment (Table 1). Aluminium was the most abundant metal, with the lowest concentration in urban water (mean $40 \mu \mathrm{g} / \mathrm{L}$ ), followed by concrete pipe water (mean $308 \mu \mathrm{g} / \mathrm{L}$ ), pristine reference water (mean $370 \mu \mathrm{g} / \mathrm{L}$ ) and largest in RCA water (mean $654 \mu \mathrm{g} / \mathrm{L}$ ). Two of the metals (manganese and strontium) were not detected in the pristine reference water. Barium was detected in the highest concentration in urban water (mean $16.3 \mu \mathrm{g} / \mathrm{L})$, then RCA water $(14.6 \mu \mathrm{g} / \mathrm{L})$. Copper was highest in water recirculated through concrete materials (concrete pipe water mean $9.6 \mu \mathrm{g} / \mathrm{L}$; RCA water mean $12.0 \mu \mathrm{g} / \mathrm{L}$ ). The largest differences in metal concentrations were found for strontium, which was not detected in reference water, compared to a mean of 43 $\mu \mathrm{g} / \mathrm{L}$ in urban water, $13.9 \mu \mathrm{g} / \mathrm{L}$ in concrete pipe water and highest at $125.6 \mu \mathrm{g} / \mathrm{L}$ in RCA water. 
Table 1

- Chemical Characteristics of Water Treatments

\begin{tabular}{|c|c|c|c|c|}
\hline & $\begin{array}{l}\text { Pristine Reference } \\
\text { BMUS water }\end{array}$ & $\begin{array}{l}\text { Urban BMUS } \\
\text { water }\end{array}$ & $\begin{array}{l}\text { Concrete Pipe water after } \\
\text { recirculation }\end{array}$ & $\begin{array}{l}\text { RCA water after } \\
\text { recirculation }\end{array}$ \\
\hline $\begin{array}{l}\text { Variables } \\
\text { (units) }\end{array}$ & Min.-Max. (Mean) & $\begin{array}{l}\text { Min.-Max. } \\
\text { (Mean) }\end{array}$ & Min.-Max. (Mean) & Min.-Max. (Mean) \\
\hline $\mathrm{pH}$ & 4.89 & 7.53 & 7.42 & 8.91 \\
\hline $\mathrm{EC}(\mu \mathrm{S} / \mathrm{cm})$ & 27.88 & 129.3 & 81.8 & 340.0 \\
\hline Arsenic $(\mu \mathrm{g} / \mathrm{L})$ & $<1$ & $<1$ & $<1$ & $3.0-5.0(3.9)$ \\
\hline $\begin{array}{l}\text { Aluminium } \\
(\mu \mathrm{g} / \mathrm{L})\end{array}$ & $340-400(370)$ & $30-50(40)$ & $260-340(308)$ & $280-990(654)$ \\
\hline Barium $(\mu \mathrm{g} / \mathrm{L})$ & 2.0 & $15-17(16.3)$ & $<1-2.0(0.85)$ & $10.0-22.0(14.6)$ \\
\hline Copper $(\mu \mathrm{g} / \mathrm{L})$ & $<1-3(1.12)$ & 2 & $6.0-13(9.6)$ & $8.0-17.0(12.0)$ \\
\hline $\begin{array}{l}\text { Manganese } \\
(\mu \mathrm{g} / \mathrm{L})\end{array}$ & $<5$ & $<5-6.0$ & $<5$ & $<5-30.0(15.1)$ \\
\hline $\begin{array}{l}\text { Strontium } \\
(\mu \mathrm{g} / \mathrm{L})\end{array}$ & $<1$ & $41-46(43)$ & $13.0-15.0(13.9)$ & $84-160(125.6)$ \\
\hline $\operatorname{Zinc}(\mu \mathrm{g} / \mathrm{L})$ & $4-10(6.2)$ & 5.0 & $11-16(13.1)$ & $6-15(9.8)$ \\
\hline $\begin{array}{l}\text { Sodium } \\
(\mathrm{mg} / \mathrm{l})\end{array}$ & $3.6-3.8(3.7)$ & $6.8-7.1(6.9)$ & $3.7-4.0(3.88)$ & $19-26(21.5)$ \\
\hline $\begin{array}{l}\text { Calcium } \\
(\mathrm{mg} / \mathrm{l})\end{array}$ & $<0.5$ & $\begin{array}{l}12.0-13.0 \\
(12.33)\end{array}$ & $8.1-8.9(8.49)$ & $27-42(34.6)$ \\
\hline $\begin{array}{l}\text { Potassium } \\
(\mathrm{mg} / \mathrm{l})\end{array}$ & $<0.5$ & $2.0-2.1(2.04)$ & $1.8-4.1(2.93)$ & $13-14(13.7)$ \\
\hline $\begin{array}{l}\text { Magnesium } \\
(\mathrm{mg} / \mathrm{l})\end{array}$ & $<0.5$ & $1.3-1.4(1.34)$ & $<0.5$ & $0.7-1.2(0.97)$ \\
\hline
\end{tabular}

\subsection{Study species and experimental setup}

The invasive willow species (Salix spp.) was chosen as a study species, as it grows quickly and is easy to grow in controlled laboratory conditions. Additionally, willows in the genus Salix were amongst nine others listed as problematic weed species in the recommended declaration of BMUS as a vulnerable ecological community (NSW Scientific Committee 2007). Salix spp. is also listed as a problematic weed species across urban streams and wetlands in the Blue Mountains and wider Sydney region (Blue Mountains City Council (BMCC) 2016) due to its ability to spread vegetatively and by seed (Webb and Erskine 2003). Willows are also common in urban, rural and other riparian zones across Australia, as they were historically planted for aesthetic benefits and to control streambank erosion caused by the prior removal of native species (Webb and Erskine 2003). Another reason for using willows as a test species was that previous research had demonstrated their ability to uptake and accumulate heavy metals in their tissue (Meers et al. 2007).

Willows have well-known detrimental effects on many Australian riparian ecosystems, including reduced channel capacity, channel diversion and erosion, increased sediment loads and increased flooding, which can affect water quality and river health (Stokes and Cunningham 2006). Hence, results of this study could help understand how contamination associated with human activity can influence the growth of this species. This information could have management implications for Salix spp. as it is classified as a noxious weed and is listed as a weed of national significance (NSW DPIE 2021). NSW DPIE considers species of willow (Salix spp.) as one of the worst weeds in Australia due to their invasive abilities and their 
economic and environmental impacts to streams and rivers, in addition to their ability to out-compete native species and dominate riparian vegetation (NSW DPIE 2017).

120 willow cuttings were randomly selected with 30 in each of the four water treatments (Figure 1). Branches of Salix spp. were collected from five parent willow trees located across the Hawkesbury-Nepean and Blue Mountains regions. More than one parent tree was selected to ensure that any growth differences across treatments were not due to the individual characteristics of any one parent tree. The branches were trimmed to approximately $30 \mathrm{~cm}$ lengths and were stripped of all leaves and shoots. A pilot study that was conducted in preparation for this experiment revealed that thicker willow cuttings showed improved growth (Purdy and Wright 2019). Thus, for this study, only cuttings with diameters from 0.3-0.6 $\mathrm{cm}$ were selected.

The willow cuttings were placed into one of four different water treatments; urban water; reference; concrete pipe water, and RCA water. Each cutting was placed individually into a cleaned and rinsed plastic $500 \mathrm{~mL}$ beaker, which was filled with $400 \mathrm{~mL}$ of the respective water treatment. The top of the beaker was covered with a plastic wrap film to minimise evaporation, with a small hole for the cutting. Willow branch collection, preparation of cuttings, and placement in beakers containing treatment solution occurred on a single day (Figure 1).

The plants were randomly assigned positions in a controlled environment growth room, where they were exposed to 24hour light (Philips 'cool white' TLD36W/840) and approximately constant temperature. Minimal temperature fluctuations occurred throughout the growth period, from 20-21 degrees Celsius, measured with a Livingstone maximum-minimum thermometer. Beakers were topped up to maintain a volume of $400 \mathrm{~mL}$ with deionised water on a fortnightly basis. The plastic film was reapplied after water testing and topping up water level.

\subsection{Harvest and plant growth measurements}

Plants were harvested after 7.5 weeks of growth. For each plant, maximum shoot and root length, stem height, the length of five random adult leaves, and whole plant wet weight were measured (Figure 2). Maximum root length was measured as the length of the longest root, with the root straightened perpendicular to the main stem or trunk of the plant. Maximum shoot length was measured as the length of the longest stem growing from the main willow trunk and leaf length was the distance of the entire blade from base to apex. Stem height refers to the total length of the main trunk of the plant, from base to tip. Wet weight was measured using an electronic balance (AND FX-3200) and separate weigh-boats were used for each plant, to prevent cross contamination.

Leaf area measurements were taken from five randomly selected plants from each treatment group. Leaves were plucked gently from the plant, placed in a scanner, and scanned in colour (Figure 3). The scanner was wiped with ethanol and allowed to dry in between plants to ensure that no contamination between plant tissue occurred. A ruler was placed on the scanner for scale. Leaf area measurements were processed using ImageJ software (Rasband 1997-2018) and the protocol developed was based on Glozer (2008).

All plants were stored in unused paper bags and kept at 20 degrees Celsius for 1.5 weeks, after which they were placed in an incubator (Labec incubator S4218) for 9 days at 38.5 degrees Celsius. Plants were removed when the weights of five random plants taken a day apart varied by less than $0.05 \mathrm{~g}$. For each plant, whole dry weight was measured. The shoots (including leaves) and roots were then separated from the main trunk and their dry weight was taken, to measure the weight of the new growth of the plant during the experimental period. Shoots and leaves were then weighed separately, as were roots. For all weight measurements, an electronic laboratory balance was used (AND FX-3200).

\subsection{Analysis of metals in plant tissue}


For analysis of metals in the dried plant tissue, each treatment group (pristine, urban, whole concrete, RCA) was divided into five replicates. Each replicate contained the shoot and root tissue from six plants.

The shoots and leaves of the tissue from six plants in each subgroup were ground up using an electronic coffee grinder (Sunbeam Multigrinder II). Shoots and leaves were placed in the coffee grinder and were ground for two to four minutes in 20 second bursts until a fine powder was produced. Each subgroup was then sieved through an 850-micron sieve and stored in a sterile plastic tube (Figure 5). In between grinding of samples, the grinder and sieve were thoroughly cleaned and then rinsed with deionised water and dried with a hairdryer, to prevent cross-contamination.

The plant tissue samples were then sent to a NATA accredited laboratory, where concentrations of 16 metals was measured: arsenic, barium, cadmium, chromium, copper, manganese, molybdenum, nickel, lead, titanium, strontium, lithium, aluminium, iron, and zinc. Metal concentrations were determined using ICP-AES (Envirolab Services Pty Ltd, personal communication 11 July 2019).

\subsection{Statistical analyses}

Data was analysed using RStudio (RStudio Team 2016). Normality of data was assessed using the Shapiro-Wilks test and homoscedasticity was evaluated using Levene's test, using the 'car' package (Fox and Weisberg 2019). As data was nonnormal $(p<0.05)$ and variances were not equal $(p<0.05)$, Kruskal-Wallis tests were used as a non-parametric alternative to assess whether differences in growth and in tissue metal concentrations were significant between treatments. The threshold of significance chosen was 0.05 , thus any results with $p$ values less than 0.05 were considered significant. $A$ Dunn's posthoc test with Bonferroni p-value correction in the 'FSA' package (Ogle, Wheeler and Dinno 2019) was used for any measurements that were shown to significantly differ to assess which treatment groups differed. All graphs and figures were produced using Microsoft Excel (Microsoft 2019).

For growth measurements, treatment group averages were calculated based on the 30 plants in each treatment group $(n=30$, total $n=120)$. For leaf area measurements, averages were calculated based on five random plants chosen from each treatment group $(n=5$, total $n=20)$. For the metal tissue content, averages were calculated based on five samples for each treatment group $(n=5$, total $n=20)$, which were each composed of 6 random plants of the same treatment group.

\section{Results}

\subsection{Plant growth}

After 7.5 weeks in the controlled environment, the leaf, shoot and root growth from the willow cuttings differed significantly between treatment groups for all measured growth parameters (Figure 2; Table 2). For length and dry weight measurements, the plants grown in RCA water were both longest and the heaviest, followed by plants grown in urban BMUS water, then plants grown in whole pipe recirculated water, and, finally, plants grown in pristine BMUS water. The mean maximum length of willow cutting shoots $(8.34 \mathrm{~cm})$ and roots $(11.79 \mathrm{~cm})$ from pristine water treatment plants were shortest, while the longest were found in plants grown in the RCA treatment (shoots $17.3 \mathrm{~cm}$; roots $27.47 \mathrm{~cm}$; Table 2). The same trend was observed for the dry weight of new willow growth. The mean dry weight of new growth was lightest for pristine treatment plants, comprising shoots and leaves $(0.40 \mathrm{~g})$ and roots $(0.07 \mathrm{~g})$. In contrast, the mean dry weight of new growth was heaviest for RCA treatment plants, comprising shoots and leaves $0.78 \mathrm{~g}$ and roots $0.23 \mathrm{~g}$ (Table 2).

There were also large differences in leaf measurements, which varied significantly according to treatment (Table 2; Figure 3). There were significant differences between leaf parameters (leaf area and number of leaves) of pristine treatment plants and urban treatment plants. Pristine treatment plants had the lowest mean number of leaves (15.8) contrasting markedly with the number of leaves from plants from the other three treatments, which were from two to three times greater, ranging from a mean of 52.8 leaves (RCA treatment) and 66.6 leaves (urban treatment) (Table 2; Figure 3). The 
total leaf area of pristine plant cuttings (mean $475.68 \mathrm{~cm}^{2}$ ) was the lowest of all the treatments. In comparison, mean leaf area was between $53.9 \%$ greater (concrete whole pipe treatment $=732.3 \mathrm{~cm}^{2}$ ) and $85.1 \%$ greater (urban plants $=880.3$ $\left.\mathrm{cm}^{2}\right)$.

Table 2

Summary statistics of measured growth parameters with significance test results, by treatment. Maximum shoot and root lengths are given to 1 decimal place, due to equipment measurement accuracy. All other measurements are given to 2 decimal places, as are chi-squared values. Significance of difference ( $p$-values) is given to 3 significant figures and significance is indicated as * $(p<0.05), * *(p<0.01)$, and *** $(p<0.001)$.

\begin{tabular}{|c|c|c|c|c|c|c|c|c|c|c|c|}
\hline \multirow[b]{2}{*}{$\begin{array}{l}\text { Plant } \\
\text { attribute }\end{array}$} & \multicolumn{2}{|l|}{ Pristine } & \multicolumn{2}{|l|}{ Urban } & \multicolumn{2}{|c|}{ Whole pipe } & \multicolumn{2}{|c|}{$20 \mathrm{~mm}$ RCA } & \multicolumn{3}{|c|}{$\begin{array}{l}\text { Kruskal-Wallis test } \\
\text { results }\end{array}$} \\
\hline & Range & Mean & Range & Mean & Range & Mean & Range & Mean & $\begin{array}{l}\text { Chi- } \\
\text { squared }\end{array}$ & df & $\begin{array}{l}P \\
\text { value }\end{array}$ \\
\hline $\begin{array}{l}\text { Max. } \\
\text { shoot } \\
\text { length } \\
\text { (cm) }\end{array}$ & $\begin{array}{l}2.2- \\
20.3\end{array}$ & 8.34 & $\begin{array}{l}6.2- \\
29.5\end{array}$ & 13.44 & $\begin{array}{l}4.4- \\
20.7\end{array}$ & 12.26 & $\begin{array}{l}4.8- \\
34.0\end{array}$ & 17.3 & 27.87 & 3 & $\underset{\star \star \star \star}{<001}$ \\
\hline $\begin{array}{l}\text { Max. } \\
\text { root } \\
\text { length } \\
\text { (cm) }\end{array}$ & $\begin{array}{l}4.5- \\
25.0\end{array}$ & 11.79 & $\begin{array}{l}9.3- \\
35.7\end{array}$ & 22.38 & $\begin{array}{l}14.1- \\
31.7\end{array}$ & 20.08 & $\begin{array}{l}4.6- \\
39.5\end{array}$ & 27.47 & 59.37 & 3 & $\underset{\star \star \star \star *}{<001}$ \\
\hline $\begin{array}{l}\text { Dry } \\
\text { weight } \\
\text { of new } \\
\text { growth } \\
\text { (g) }\end{array}$ & $\begin{array}{l}0.10- \\
1.53\end{array}$ & 0.47 & $\begin{array}{l}0.25- \\
2.06\end{array}$ & 0.90 & $\begin{array}{l}0.17- \\
1.40\end{array}$ & 0.73 & $\begin{array}{l}0.01- \\
1.71\end{array}$ & 0.98 & 29.03 & 3 & $\underset{\star \star \star \star}{<0.001}$ \\
\hline $\begin{array}{l}\text { Dry } \\
\text { weight } \\
\text { of } \\
\text { shoots } \\
\text { and } \\
\text { leaves } \\
\text { (g) }\end{array}$ & $\begin{array}{l}0.08- \\
1.41\end{array}$ & 0.40 & $\begin{array}{l}0.17- \\
1.87\end{array}$ & 0.78 & $\begin{array}{l}0.12- \\
1.26\end{array}$ & 0.61 & $\begin{array}{l}0.33- \\
1.45\end{array}$ & 0.78 & 25.72 & 3 & $\underset{\star \star \star * \star}{<001}$ \\
\hline $\begin{array}{l}\text { Dry } \\
\text { weight } \\
\text { of roots } \\
\text { (g) }\end{array}$ & $\begin{array}{l}0.02- \\
0.16\end{array}$ & 0.07 & $\begin{array}{l}0.06- \\
0.20\end{array}$ & 0.11 & $\begin{array}{l}0.04- \\
0.17\end{array}$ & 0.10 & $\begin{array}{l}0.08- \\
0.61\end{array}$ & 0.23 & 55.78 & 3 & $\underset{\star \star \star * *}{<001}$ \\
\hline $\begin{array}{l}\text { Average } \\
\text { number } \\
\text { of } \\
\text { leaves }\end{array}$ & $5-35$ & 15.80 & $46-98$ & 66.60 & $\begin{array}{l}34- \\
69\end{array}$ & 55.40 & $29-89$ & 52.80 & 10.34 & 3 & ${ }_{\star}^{0.0158}$ \\
\hline $\begin{array}{l}\text { Total } \\
\text { leaf area } \\
\left(\mathrm{cm}^{2}\right)\end{array}$ & $\begin{array}{l}273.0 \\
-735.6\end{array}$ & 475.68 & $\begin{array}{l}731.1 \\
- \\
1463.5\end{array}$ & 880.32 & $\begin{array}{l}724.1 \\
- \\
735.7\end{array}$ & 732.34 & $\begin{array}{l}735.4 \\
- \\
1449.4\end{array}$ & 878.30 & 8.37 & 3 & 0.0390 \\
\hline
\end{tabular}

\subsection{Metal concentrations in willow tissue}

Differences in mean content of seven metals were observed in the tissue of plants grown in the four different water treatments (Table 3; Figure 5). The concentration of three metals (barium, strontium, and aluminium) in plant tissue varied significantly according to treatment (Table 3). A Dunn's post-hoc test revealed that barium concentrations differed significantly between pristine and RCA treatment plants, while strontium concentrations were significantly different for pristine and RCA treatment plants and for RCA and concrete pipe treatment plants. 
Barium concentrations recorded the greatest overall percentage increase in metal concentrations in plant tissue grown in different treatments (Table 3). When comparing the barium content in plant tissue grown in pristine BMUS water to plants grown in the other three treatments as a percentage increase, the greatest percentage increase was between pristine (mean barium $16.4 \mathrm{mg} / \mathrm{kg}$ ) and RCA plants (mean barium $41.6 \mathrm{mg} / \mathrm{kg}$ ) with an approximate increase of 154\% (Table 3). The trend was similar for strontium concentrations between pristine (mean $28.8 \mathrm{mg} / \mathrm{kg}$ ) and RCA plants (mean 68.4 $\mathrm{mg} / \mathrm{kg}$ ), with an increase of approximately $137 \%$ (Table 3 ). For aluminium, the pattern was the opposite, with the largest concentrations found in pristine plants (mean $11.6 \mathrm{mg} / \mathrm{kg}$ ) compared to all other treatments (urban, whole pipe and RCA), for which mean aluminium concentrations ranged from $8.0-8.8 \mathrm{mg} / \mathrm{kg}$.

Table 3

Summary statistics for concentrations of selected metals in dried willow tissue $(\mathrm{mg} / \mathrm{kg})$ for which differences were observed across treatment groups. Average metal concentrations are presented to 2 decimal places, as are chi-squared values. Significance of difference ( $p$-values) is given to 3 significant figures and significance is indicated as * $(p<0.05)$, ** $(\mathrm{p}<0.01)$, and $* \star \star *(p<0.001)$

\begin{tabular}{|c|c|c|c|c|c|c|c|c|c|c|c|}
\hline \multirow[b]{2}{*}{$\begin{array}{l}\text { Metal } \\
(\mathrm{mg} / \mathrm{kg})\end{array}$} & \multicolumn{2}{|l|}{ Pristine } & \multicolumn{2}{|l|}{ Urban } & \multicolumn{2}{|c|}{ Whole pipe } & \multicolumn{2}{|c|}{20 mm RCA } & \multicolumn{3}{|c|}{ Kruskal-Wallis test results } \\
\hline & Range & Mean & Range & Mean & Range & Mean & Range & Mean & $\begin{array}{l}\text { Chi- } \\
\text { squared }\end{array}$ & df & $p$ value \\
\hline Barium & $\begin{array}{l}12.00 \\
- \\
21.00\end{array}$ & 16.40 & $\begin{array}{l}22.00 \\
- \\
27.00\end{array}$ & 23.83 & $\begin{array}{l}20.00 \\
- \\
29.00\end{array}$ & 23.50 & $\begin{array}{l}36.00- \\
50.00\end{array}$ & 41.60 & 16.73 & 3 & 0.000803 \\
\hline Copper & $\begin{array}{l}8.00- \\
23.00\end{array}$ & 14.00 & $\begin{array}{l}6.00- \\
12.00\end{array}$ & 10.00 & $\begin{array}{l}11.00 \\
-14.00\end{array}$ & 12.00 & $\begin{array}{l}8.00- \\
12.00\end{array}$ & 10.40 & 6.40 & 3 & 0.0935 \\
\hline Manganese & $\begin{array}{l}60.00 \\
- \\
110.00\end{array}$ & 76.00 & $\begin{array}{l}68.00 \\
- \\
88.00\end{array}$ & 75.67 & $\begin{array}{l}63.00 \\
- \\
98.00\end{array}$ & 79.50 & $\begin{array}{l}69.00 \\
- \\
100.00\end{array}$ & 89.20 & 3.72 & 3 & 0.294 \\
\hline Strontium & $\begin{array}{l}24.00- \\
36.00\end{array}$ & 28.80 & $\begin{array}{l}38.00 \\
- \\
43.00\end{array}$ & 40.83 & $\begin{array}{l}33.00 \\
- \\
34.00\end{array}$ & 36.67 & $\begin{array}{l}56.00- \\
81.00\end{array}$ & 68.40 & 17.47 & 3 & $\underbrace{0.000567}_{\star \star \star}$ \\
\hline Aluminium & $\begin{array}{l}8.00- \\
18.00\end{array}$ & 11.60 & $\begin{array}{l}4.00- \\
7.00\end{array}$ & 8.80 & $\begin{array}{l}7.00- \\
10.00\end{array}$ & 8.00 & $\begin{array}{l}6.00- \\
13.00\end{array}$ & 8.80 & 12.89 & 3 & 0.00489 \\
\hline Iron & $\begin{array}{l}39.00 \\
- \\
110.00\end{array}$ & 61.00 & $\begin{array}{l}45.00 \\
- \\
80.00\end{array}$ & 58.67 & $\begin{array}{l}44.00 \\
- \\
59.00\end{array}$ & 52.83 & $\begin{array}{l}58.00 \\
- \\
72.00\end{array}$ & 64.20 & 4.21 & 3 & 0.239 \\
\hline Zinc & $\begin{array}{l}37.00- \\
75.00\end{array}$ & 54.80 & $\begin{array}{l}33.00 \\
- \\
67.00\end{array}$ & 50.67 & $\begin{array}{l}48.00 \\
-67.00\end{array}$ & 61.33 & $\begin{array}{l}42.00- \\
100.00\end{array}$ & 61.80 & 1.69 & 3 & 0.639 \\
\hline
\end{tabular}

\section{Discussion}

Willow cuttings in this study demonstrated increased growth in treatments of urban water and pristine water exposed to concrete, compared to willows grown in unmodified pristine water. Overall, from all measured growth parameters, willows grown in RCA recirculated water showed the greatest growth, followed by plants grown in urban BMUS water, then those grown in whole concrete pipe recirculated water, and, finally, willows grown in pristine BMUS water. Results suggest that exposure of water to concrete materials contribute to favourable water geochemistry for the growth of the willow, Salix spp., which is regarded as an Australian weed of national significance. Salix spp. is also identified as an invasive weed of concern for the conservation of endangered BMUS ecological communities (NSW Scientific Committee 2007).

These findings are supported by an earlier pilot study, which recorded increased growth of willow cuttings in reference BMUS water circulated through a concrete pipe for two hours, when compared with cuttings in reference water that had 
not been exposed to concrete (Purdy and Wright 2019). To the best of our knowledge, there are no other laboratory studies investigating how water exposed to concrete may affect the growth of an invasive weed species and, thus, the results of this study and our previous study (Purdy and Wright 2019) appear to be unique. These results add to the growing knowledge of how widespread urban materials, such as concrete, can affect the natural environment.

Urban riparian zones and urban wetlands are frequently dominated by vigorous growth of weed species, often to the detriment of native species (Ehrenfeld and Schneider 1991; Grella, Renshaw and Wright 2018; Leishman, Hughes and Gore 2004). Previous research widely attributes the dominance of invasive plant species in urban riparian zones to elevated nitrogen and phosphorous levels in water and riparian soil (Paul and Meyer 2001). However, in the case of BMUS, weed invasions are prevalent in wetlands of urban catchments that do not have increased nitrogen and phosphorous concentrations in the water (Carroll, Wright and Reynolds 2018). The results of this study highlight other anthropogenic factors, such as higher $\mathrm{pH}$ and increased concentration of metals and ions, that contribute to favourable growth conditions for urban invasive weeds.

The other key finding in this study is that water exposed to concrete can increase the growth of invasive weeds. This adds further support to the theory that urban concrete materials in the built environment can be a potential source of modified geochemistry in urban waters and soils and therefore can contribute to the chemical and the ecological degradation of urban streams and wetlands (Belmer, Tippler and Wright 2018; Davies et al. 2010; Grella, Renshaw and Wright 2018; Kaushal et al. 2013; Tippler, Wright and Hanlon 2012; Wright et al. 2011).

Water in the four treatments used to grow willow cuttings in this study had varying pH levels, from a mean of 4.89 in pristine reference BMUS water to 8.91 in the RCA treated water. Urban BMUS water had a pH of 7.53, while water exposed to a whole concrete pipe had a $\mathrm{pH}$ of 7.42. This was in accordance with previous studies of pristine non-urban BMUS water that often record $\mathrm{pH}<5$, with urban BMUS generally reporting $\mathrm{pH}>6$ (Belmer, Wright and Tippler 2015; Carroll, Reynolds and Wright 2020). It is well known that pH plays an important role influencing plant growth through the bioavailability and uptake of nutrients and toxicity of metals (Alam, Naqvi and Ansari 1999; Charman and Murphy 2007; Murrmann and Peech 1969; Wang et al. 2006). Previous research has reported that pH differences can be highly influential to plant growth, including weed growth (Buchanan, Hoveland and Harris 1975). For example, an experimental study using tomato seedlings reported that when soil pH of was at both 4 and 8 , plant growth was diminished, but at a pH of 6 , plant growth was optimal (Kang et al. 2011). Riparian soils have also recorded substantial pH differences in urban versus nonurban catchments (Grella, Renshaw and Wright 2018). Grella, Renshaw and Wright (2018) reported that the mean riparian soil pH was 5.0 in catchments with low coverage of urban development and was 6.49 in catchments with highest coverage of urban development. That study also found that riparian soil $\mathrm{pH}$ was the single most highly correlated factor associated with variation in riparian vegetation, with higher $\mathrm{pH}$ urban soils having greater coverage by invasive weeds (Grella, Renshaw and Wright 2018). It is likely that pH differences in water treatments in this study contributed to the observed growth differences.

In the current study, elevated potassium and calcium concentrations in urban and both concrete water treatments were also likely contributors to the increased growth of willow cuttings observed in these treatments. Calcium and potassium are both regarded as essential plant nutrients and are integral for numerous functions essential for plant growth (Burstrom 1968; Groffman and Fisk 2011; Schachtman and Schroeder 1994). Potassium is very important for plant growth as it is generally the most abundant cation in plants (Schachtman and Schroeder 1994). Two previous investigations of soils and weeds in sandstone-derived soils in the Sydney area (Grella, Renshaw and Wright 2018; King and Buckney 2000) reported increased weed growth in urban soils with higher calcium and potassium content, compared to naturally forested riparian soils. Another study (Carroll, Reynolds and Wright 2020) tested the major ion contents of plant foliage growing in urban and non-urban BMUS. Potassium accounted for a mean of $3129 \mathrm{mg} / \mathrm{kg}$ of dried plant tissue in non-urban BMUS foliage, representing $33 \%$ of combined major cations content. The same study found that plant tissue from urban BMUS foliage

Page $11 / 23$ 
had substantially (5.5 times more) greater potassium content (mean $17740 \mathrm{mg} / \mathrm{kg}$ ) than non-urban plants, which accounted for $61 \%$ of the combined major cations content.

This study adds to the growing recognition that urbanisation can influence the environmental geochemistry and ecology of urban water and soil (Chambers et al. 2016; Kaushal et al. 2013). Many researchers have recognised the weathering of urban concrete material, such as concrete paths, drainage pipes and gutters, as a potential source of elevated pH and ions; for example, calcium and potassium (Borris et al. 2017; Davies et al. 2010; Kaushal et al. 2005; Kaushal et al. 2013; Moore et al. 2017; Wright et al. 2011). Such anthropogenic modified geology has been termed as 'urban karst' (Chambers et al. 2016; Kaushal et al. 2013). The current study adds further support to the hypothesis that a substantial proportion of the elevated $\mathrm{pH}$, calcium and potassium detected in urban BMUS and other urban soils and waterways across the Sydney and Blue Mountains is due to mineral leaching of concrete materials (Davies et al. 2010; Grella, Renshaw and Wright 2018; Tippler, Wright and Hanlon 2012). The exposure of concrete materials (concrete pipe, RCA fragments) to non-urban BMUS water, used as two of the treatments to grow willow cuttings in this study, resulted in higher $\mathrm{pH}$ and elevated concentrations of calcium and potassium, both of which are comparable to research reported for urban BMUS (Belmer, Wright and Tippler 2015; Carroll, Reynolds and Wright 2020; Purdy, Reynolds and Wright 2020).

The strontium and barium contents in tissue samples from willow cuttings grown in the three urban/concrete water treatments (urban, concrete pipe and $20 \mathrm{~mm} \mathrm{RCA}$ ) were more elevated than those grown in the reference treatment. This was similar to a previous pilot study for the current research (Purdy and Wright 2019). The previous study also grew willow cuttings for 7 weeks in two water treatments. One was water from a non-urban BMUS and the other treatment was a sample of water from the same BMUS that was recirculated through an unused concrete pipe. The major difference between this study and the previous study was that the water in the previous study was recirculated for 120 minutes, double the 60 minutes used in the current study. The previous study also recorded a large increase in both barium and strontium in willow tissue grown in the concrete pipe treatment. Another study of water quality in urban and non-urban BMUS also measured barium and strontium at much higher concentration (barium 4.5 times and strontium 30 times) in urban compared to non-urban locations (Carroll, Reynolds and Wright 2020). The water quality and bioaccumulation results suggest that barium and strontium may be a useful as a marker of concrete exposure, based on the results of this study and previous research (Carroll, Reynolds and Wright 2020; Purdy, Reynolds and Wright 2020; Purdy and Wright 2019).

Urban concrete materials are likely to contribute to a substantial proportion of strontium and barium in urban waters. Strontium particularly is often one of the most abundant trace elements in many concrete materials (Graham, Goguel and St John 2000; Long, Zhang and Luo 2019) depending on the source and formulation of ingredients used. Strontium is likely to be in many Australian concrete products due to the widespread use of coal-derived fly-ash in Australian concrete materials. It has been estimated that Australian concretes commonly contain up to $5 \%$ fly-ash (Ash Development Association of Australia (ADDA) 2009). Fly-ash itself often has a substantial strontium content, with United States fly ash reported to contain an average of $1334 \mathrm{ppm}$ of strontium (Straughan et al. 1981). Trace metal analysis of Australian flyash revealed that strontium was the second most abundant metal (360 ppm), second to barium (490 ppm) (Ward et al. 2009). Our suggestion that strontium may be a marker of urban and concrete exposure is not completely novel. It has previously been suggested that strontium can be used as a soil, water, and plant marker of coal combustion residue, particularly from fly ash (Hurst, Davis and Elseewi 1991; Straughan et al. 1981). Several studies have revealed that plants are able to bioaccumulate strontium into leaf and root tissue, sometimes damaging the plant (Burger and Lichtscheidl 2019). Straughan et al. (1981) has also reported that strontium can be readily bioavailable, as demonstrated when plants grown in soil containing an $8 \%$ fly ash mixture accumulated strontium in leaf tissue at up to $300 \mathrm{ppm}$. That was about 2.5 times greater than the maximum strontium content of 81 ppm recorded in the current study, in the willow leaf tissue grown in the RCA water treatment. 
The current research builds on previous studies and highlights the likely contribution of concrete urban materials to the geochemistry of urban waterways (Davies et al. 2010; Kaushal et al. 2013; Cook et al. 2020). Weed invasion is one of the major environmental degradation issues in urban waterways (Paul and Meyer 2001) and in BMUS wetlands within urbanised catchment areas (Benson and Baird 2012; Fryirs, Freidman and Kohlhagen 2012). About one-third of the BMUS wetlands are exposed to urban development, which reduces their integrity through erosion, sedimentation, modified hydrology and weed invasion (NSW Scientific Committee 2007). In the current study, the contribution of concrete materials to increased growth of Salix spp. was probably enhanced by the naturally acidic and soft water of BMUS, which has underlying geology containing negligible calcium and potassium (Belmer, Wright and Tippler 2015; Carroll, Reynolds and Wright 2020; Purdy, Reynolds and Wright 2020). It is probable that urban development in landscapes containing karst geology probably has lesser geochemical impacts (water and soil) when contrasting natural versus urban catchments.

We recommend that more research is needed to investigate the contribution that concrete can have on urban water, urban soil and on invasive species in urban riparian environments. It would be beneficial to conduct further testing on how water exposed to concrete affects other invasive weed species and a range of native species, similar to the experimental exposure of phosphorus to native plants by Leishman and Thomson (2005). It would also be valuable to extend the length

of plant studies for longer periods and across different plant growth stages. Further research on topics such as this will be vital in many environmental settings, as concrete is a ubiquitous urban material and will continue to be part of the built environment in an increasingly urban world (Cooke et al. 2020; Kaushal et al. 2013).

\section{Declarations}

\section{Acknowledgments:}

This research was conducted as part of the senior author's Master of Science research, using facilities and equipment of Western Sydney University's School of Science. We particularly thank Sue Cusbert and Michael Franklin for their generous technical support assistance. Thanks to Paul Fahey and Russell Thomson for statistical advice and for assistance with data analyses. We also thank Rani Carroll, Nakia Belmer and Holly Nettle for their manuscript review.

\section{Funding}

This research was conducted as part of the senior author's Master of Science research. The research was supported by Western Sydney University postgraduate funding.

\section{Contributions}

The design of the study was by KP, IW and JR. Field work was conducted by KP and IW. Laboratory work was by KP. Statistical analysis was by KP. All authors drafted, reviewed and approved the final manuscript for submission.

\section{Conflict of interest/ competing interests}

We declare we have no conflicts of interest and no competing interests.

\section{Ethics approval}

Not applicable.

\section{Code availability}

Not applicable.

\section{Data availability}


The data will be made available via email to the corresponding author on request.

\section{Consent for publication}

I, lan Alexander Wright, give my consent for Urban Ecosystems publish my manuscript entitled: 'The influence of concrete and urban water quality on the growth of an invasive weed (Salix spp.) in one of Australia's most endangered aquatic environments'.

\section{References}

1. Akasaka M, Osawa T, Ikegami M 2015, 'The role of roads and urban area in occurrence of an ornamental invasive weed: a case of Rudbeckia laciniata L', Urban Ecosyst, vol. 18, no. 3, pp. 1021-1030, doi: 10.1007/s11252-015-0466-4

2. Alam SM, Naqvi SSM, Ansari R (1999) 'Impact of soil pH on nutrient uptake by crop plants'. In: Pessaraldi M (ed) Handbook of Plant and Crop Stress. Marcel Dekker, New York, pp 51-60

3. Ash Development Association of Australia (ADDA) 2009, Guide to the use of fly-ash in concrete in Australia - Fly ash data reference sheet number 1, viewed 20 November 2019, http://www.adaa.asn.au/uploads/default/files/adaaref_data_sheet_1.pdf

4. Belmer N, Tippler C, Wright I (2018) 'Aquatic Ecosystem Degradation of High Conservation Value Upland Swamps, Blue Mountains Australia'. Water Air Soil Pollution 229(3):1-8. doi:10.1007/s11270-018-3688-2

5. Belmer N, Wright I, Tippler C (2015) 'Urban geochemical contamination of high conservation value upland swamps, Blue Mountains Australia'. Water Air Soil Pollution 226(10):1-5. doi:10.1007/s11270-015-2607-z

6. Benson D, Baird IRC 2012, 'Vegetation, fauna and groundwater interrelations in low nutrient temperate montane peat swamps in the upper Blue Mountains, New South Wales', Cunninghamia, vol. 12, no. 4, pp. 267-307, doi: 10.7751/cunninghamia.2012.12.021

7. Blue Mountains City Council (BMCC) 2016, Blue Mountains Swamps in the Sydney Basin Bioregion - vulnerable ecological community listing, viewed 7 October 2018 https://www.environment.nsw.gov.au/determinations/BlueMountainsSwampsVulnerableEcologicalCommunity.htm

8. Borris M, Österlund H, Marsalek J, Viklander M (2017) 'An exploratory study of the effects of stormwater pipeline materials on transported stormwater quality'. Water Science Technology vol 76(2):247-255. doi:10.2166/wst.2017.195

9. Buchanan GA, Hoveland CS, Harris MC (1975) 'Response of Weeds to Soil pH'. Weed Sci 23(6):473-477. doi:10.1017/S004317450006505X

10. Burger A, Lichtscheidl I 2019, 'Strontium in the environment: Review about reactions of plants towards stable and radioactive strontium isotopes', The Science of the total environment, vol. 653, no., pp. 1458-1512, doi: 10.1016/j.scitotenv.2018.10.312

11. Burstrom HG 1968, 'CALCIUM AND PLANT GROWTH', Biological Reviews, vol. 43, no. 3, pp. 287-316, doi: https://doi.org/10.1111/j.1469-185X.1968.tb00962.x

12. Buszewski B, Jastrzebska A, Kowalkowski T, Gorna-Binkul A 2000, 'Monitoring of selected heavy metals uptake by plants and soils in the area of Torun, Poland', Polish Journal of Environmental Studies, vol. 9, no. 6, pp. 511-515, accessed 28 November 2019, http://www.pjoes.com/Monitoring-of-Selected-Heavy-Metals-Uptake-by-Plants-andSoils-in-the-Area-of-Torun,87340,0,2.html

13. Carroll R, Reynolds JK, Wright IA 2020, 'Geochemical signature of urbanisation in Blue Mountains Upland Swamps', Science of The Total Environment, vol. 699, no., pp. 134393, doi: https://doi.org/10.1016/j.scitotenv.2019.134393

14. Carroll R, Wright I, Reynolds J 2018, 'Is geochemical contamination from urban development contributing to weed invasions in high conservation value wetlands?', paper presented at 9th Australian Streams Management Conference,

Page $14 / 23$ 
Hobart, Tasmania, viewed 1 July 2019

15. Chambers LG, Chin Y-P, Filippelli GM, Gardner CB, Herndon EM, Long DT, Lyons WB, Macpherson GL, McElmurry SP, McLean CE, Moore J, Moyer RP, Neumann K, Nezat CA, Soderberg K, Teutsch N, Widom E 2016, 'Developing the scientific framework for urban geochemistry', Applied Geochemistry, vol. 67, no. C, pp. 1-20, doi:

10.1016/j.apgeochem.2016.01.005

16. Charman PEV, Murphy BW (2007) Soils: their properties and management, 3rd edn. Oxford University Press, South Melbourne, Vic, edn, South Melbourne

17. Cockel C, Gurnell A 2012, 'An investigation of the composition of the urban riparian soil propagule bank along the River Brent, Greater London, UK, in comparison with previous propagule bank studies in rural areas', Urban Ecosyst, vol. 15, no. 2, pp. 367-387, doi: 10.1007/s11252-011-0203-6

18. Connor NP, Sarraino S, Frantz DE, Bushaw-Newton K, Macavoy SE 2014, 'Geochemical characteristics of an urban river: influences of an urban landscape', Applied Geochemistry, vol. 47, no. 1, pp. 209-216, doi:

10.1016/j.apgeochem.2014.06.012

19. Conway TM (2007) 'Impervious surface as an indicator of $\mathrm{pH}$ and specific conductance in the urbanizing coastal zone of New Jersey, USA'. J Environ Manage 85(2):308-316. doi:10.1016/j.jenvman.2006.09.023

20. Cooke SJ, Bergman JN, Nyboer EA, Reid AJ, Gallagher AJ, Hammerschlag N, Van de Riet K, Vermaire JC 2020, 'Overcoming the concrete conquest of aquatic ecosystems', Biological conservation, vol. 247, no., pp. 108589, doi: 10.1016/j.biocon.2020.108589

21. Davies P, Wright I, Jonasson O, Findlay S (2010) 'Impact of concrete and PVC pipes on urban water chemistry'. Urban Water Journal 7(4):233-241. doi:10.1080/1573062X.2010.484502

22. Dean M, Tippler C 2016, 'Assessing riparian vegetation and creek channel condition in a rapidly changing urban space: A case study from Blacktown LGA', paper presented at 8th Annual Australian Stream Management Conference, Leura, NSW, viewed 30 October 2019

23. DECCW (NSW Department of Environment, C.C.a.W. 2010, Specification for supply of recycled material for pavements, earthworks and drainage, viewed 29 August 2021, https://www.epa.nsw.gov.au/-/media/epa/corporatesite/resources/waste/100004-supply-recycled-material.pdf? la=en\&hash=7BDBD041B1287DFCEA8C399BBEB328B922C88C9E

24. Department of the Environment and Energy (DEE) 2019, Temperate Highland Peat Swamps on Sandstone in Community and Species Profile and Threats Database, viewed 31 October 2019, http://www.environment.gov.au/sprat

25. Ehrenfeld J, Schneider J (1991) 'Chamaecyparis thyoides wetlands and suburbanization: effects on hydrology, water quality and plant community composition'. J Appl Ecol 28(2):467-490. doi:10.1016/0006-3207(92)90664-9

26. Fox J, Weisberg S, An R (2019) Companion to Applied Regression. Sage, https://socialsciences.mcmaster.ca/jfox/Books/Companion/

27. Fryirs K, Freidman B, Kohlhagen T 2012, 'The formation and geomorphic condition of upland swamps in the Blue Mountains: Rehabilitation potential of these endangered ecosystems', paper presented at 6th Australian Stream Management Conference, 6-8 February 2012, Canberra, Australia, viewed 31 October 2019, http://www.asm6.org.au/assets/6ASM/Abstracts/205.pdf

28. Glozer K 2008, Protocol for Leaf Image Analysis - Surface Area, viewed 09/10/2019 http://ucanr.edu/sites/fruittree/files/49325.pdf

29. Gorissen S, Greenlees M, Shine R 2017, 'Habitat and Fauna of an Endangered Swamp Ecosystem in Australia's Eastern Highlands', Wetlands, vol. 37, no. 2, pp. 269-276, doi: 10.1007/s13157-016-0865-1

30. Gorissen S, Mallinson J, Greenlees M, Shine R 2015, 'The impact of fire regimes on populations of an endangered lizard in montane south-eastern Australia', Austral ecology, vol. 40, no. 2, pp. 170-177, doi: 10.1111/aec.12190 
31. Graham IJ, Goguel RL, St John DA 2000, 'Use of strontium isotopes to determine the origin of cement in concretes: Case examples from New Zealand', Cement and concrete research, vol. 30, no. 7, pp. 1105-1111, doi: 10.1016/S00088846(00)00248-9

32. Grella C, Renshaw A, Wright I 2018, 'Invasive weeds in urban riparian zones: the influence of catchment imperviousness and soil chemistry across an urbanization gradient', Urban Ecosystems, vol. 21, no. 3, pp. 505-517, doi: 10.1007/s11252-018-0736-z

33. Grella C, Wright IA, Findlay SJ, Jonasson OJ (2014) 'Geochemical contamination of urban water by concrete stormwater infrastructure: applying an epoxy resin coating as a control treatment'. Urban Water Journal 13(2):1-8. doi:10.1080/1573062X.2014.951660

34. Groffman PM, Fisk MC 2011, 'Calcium constrains plant control over forest ecosystem nitrogen cycling', Ecology, vol. 92, no. 11, pp. 2035-2042, doi: https://doi.org/10.1890/11-0461.1

35. Gurnell A, Lee M, Souch C (2007) 'Urban Rivers: Hydrology, Geomorphology, Ecology and Opportunities for Change'. Geography Compass 1(5):1118-1137. doi:10.1111/j.1749-8198.2007.00058.x

36. Hensen M, Mahony E 2010, 'Reversing Drivers of Degradation in Blue Mountains and Newnes Plateau Shrub Swamp Endangered Ecological Communities', Australasian Plant Conservation: Journal of the Australian Network for Plant Conservation, vol. 18, no. 4, pp. 5-6, accessed https://trove.nla.gov.au/work/81045681?q\&versionld=94327960

37. Hurst RW, Davis TE, Elseewi AA 1991, 'Strontium isotopes as tracers of coal combustion residue in the environment', Engineering geology, vol. 30, no. 1, pp. 59-77, doi: 10.1016/0013-7952(91)90035-J

38. Kang Y-I, Park J-M, Kim S-H, Kang N-J, Park K-S, Lee S-Y, Jeong BR (2011) 'Effects of root zone pH and nutrient concentration on the growth and nutrient uptake of tomato seedlings'. J Plant Nutr 34(5):640-652. doi:10.1080/01904167.2011.540621

39. Kaushal S, Groffman P, Likens G, Belt K, Stack W, Kelly V, Band L, Fisher G (2005) 'Increased salinization of fresh water in the northeastern United States'. Proc Natl Acad Sci USA 102(38):13517-13520. doi:10.1073/pnas.0506414102

40. Kaushal S, Likens GE, Utz RM, Pace ML, Grese M, Yepsen M 2013, 'Increased river alkalinization in the Eastern U.S', Environmental science \& technology, vol. 47, no. 18, pp. 10302, doi: 10.1021/es401046s

41. King SA, Buckney RT 2000, 'Urbanization and exotic plants in northern Sydney streams', Austral Ecology, vol. 25, no. 5, pp. 455-461, doi: 10.1046/j.1442-9993.2000.01085.x

42. King SA, Buckney RT 2002, 'Invasion of exotic plants in nutrient-enriched urban bushland', Austral Ecology, vol. 27, no. 5, pp. 573-583, doi: 10.1046/j.1442-9993.2002.01220.x

43. Leishman M, Hughes M, Gore D (2004) 'Soil phosphorus enhancement below stormwater outlets in urban bushland: spatial and temporal changes and the relationship with invasive plants'. Aust J Soil Res 42(2):197-202. doi:10.1071/SR03035

44. Leishman M, Thomson V (2005) 'Experimental evidence for the effects of additional water, nutrients and physical disturbance on invasive plants in low fertility Hawkesbury Sandstone soils, Sydney, Australia'. J Ecol 93(1):38-49. doi:10.1111/j.1365-2745.2004.00938.x

45. Long J, Zhang S, Luo K 2019, 'Element concentration and enrichment patterns in Carboniferous coal from coalburning endemic area, Yunnan province', Energy exploration \& exploitation, vol. 37, no. 5, pp. 1599-1616, doi: $10.1177 / 0144598719825703$

46. Meers E, Vandecasteele B, Ruttens A, Vangronsveld J, Tack FMG 2007, 'Potential of five willow species (Salix spp.) for phytoextraction of heavy metals', Environmental and Experimental Botany, vol. 60, no. 1, pp. 57-68, doi: 10.1016/j.envexpbot.2006.06.008

47. Meyer JL, Paul MJ, Taulbee WK (2005) 'Stream ecosystem function in urbanizing landscapes'. Journal of the North American Benthological Society 24(3):602-612. doi:10.1899/04-021.1

48. Microsoft, Excel for Office 365, Microsoft, 2019

Page $16 / 23$ 
49. Moore J, Bird DL, Dobbis SK, Woodward G 2017, 'Nonpoint Source Contributions Drive Elevated Major lon and Dissolved Inorganic Carbon Concentrations in Urban Watersheds', Environmental Science and Technology Letters, vol. 4, no. 6, pp. 198-204, doi: 10.1021/acs.estlett.7b00096

50. Murrmann RP, Peech M 1969, 'RELATIVE SIGNIFICANCE OF LABILE AND CRYSTALLINE PHOSPHATES IN SOIL', Soil science, vol. 107, no. 4, pp. 249-255, doi: 10.1097/00010694-196904000-00003

51. NSW DPIE 2017, Willows - Salix spp., viewed 29 August 2021, https://weeds.dpi.nsw.gov.au/Weeds/Willows

52. NSW DPIE 2021, Weeds of National Significance, viewed 29 August 2021, https://www.dpi.nsw.gov.au/biosecurity/weeds/weed-categories

53. NSW Scientific Committee 2007, Final Determination: Blue Mountains Swamps in the Sydney Basin Bioregion vulnerable ecological community listing, viewed 29 August 2021, https://www.environment.nsw.gov.au/topics/animals-and-plants/threatened-species/nsw-threatened-speciesscientific-committee/determinations/final-determinations/2004-2007/blue-mountains-swamps-sydney-basinbioregion-vulnerable-ecological-community-listing

54. Ogle D, Wheeler P, Dinno A, FSA: Fisheries Stock Analysis, https://github.com/droglenc/FSA, 2019

55. Oliveira H 2012, 'Chromium as an environmental pollutant: insights on induced plant toxicity', Journal of Botany, vol. 2012, no. 1, pp. 74-81, doi: 10.1155/2012/375843

56. Park S-J, Cheng Z, Yang H, Morris E, Sutherland M, McSpadden Gardener B, Grewal P 2010, 'Differences in soil chemical properties with distance to roads and age of development in urban areas', Urban Ecosyst, vol. 13, no. 4, pp. 483-497, doi: 10.1007/s11252-010-0130-y

57. Paul M, Meyer J 2001, 'Streams in the urban landscape', Annual Review of Ecology and Systematics, vol. 32, no. 1, pp. 333-365, doi: 10.1146/annurev.ecolsys.32.081501.114040

58. Purdy K, Reynolds JK, Wright IA 2020, 'Potential water pollution from recycled concrete aggregate material', Marine and freshwater research, vol., pp. doi: 10.1071/MF19354

59. Purdy K, Wright I 2019, 'Impact of concrete on riparian ecosystems', IOP Conference Series: Earth and Environmental Science, vol. 344, no. 1, pp. 1-7, doi: 10.1088/1755-1315/344/1/012033

60. Rahman M, Imteaz M, Arulrajah A, Disfani MM (2014) 'Suitability of recycled construction and demolition aggregates as alternative pipe backfilling materials'. J Clean Prod 66:no., pp. 75-84. doi:10.1016/j.jclepro.2013.11.005

61. Rasband W, ImageJ US National Institutes of Health, Bethesda, Maryland, USA, https://imagej.nih.gov/ij/, 1997-2018

62. RStudio, Team, RStudio: Integrated Development for R, RStudio Inc., http://www.rstudio.com, 2016

63. Samways MJ, Taylor S (2004) 'Impacts of invasive alien plants on Red-Listed South African dragonflies (Odonata): working for water'. South Afr J Sci 100(1):78-80, doi

64. Schachtman DP, Schroeder JI (1994) 'Structure and transport mechanism of a high-affinity potassium uptake transporter from higher plants'. Nature 370(6491):655-658. doi:10.1038/370655a0

65. Shaw P, Reeve N 2008, 'Influence of a parking area on soils and vegetation in an urban nature reserve', Urban Ecosystems, vol. 11, no. 1, pp. 107-120, doi: 10.1007/s11252-007-0044-5

66. Stokes KE, Cunningham SA (2006) 'Predictors of recruitment for willows invading riparian environments in south-east Australia: implications for weed management'. J Appl Ecol 43(5):909-921. doi:10.1111/j.1365-2664.2006.01203.x

67. Straughan IR, Elseewi AA, Page AL, Kaplan IR, Hurst RW, Davis TE 1981, 'Fly Ash-Derived Strontium as an Index to Monitor Deposition from Coal-Fired Power Plants', Science (American Association for the Advancement of Science), vol. 212, no. 4500, pp. 1267-1269, doi: 10.1126/science.212.4500.1267

68. Tchounwou PB, Yedjou CG, Patlolla AK, Sutton DJ 2012, 'Heavy metal toxicity and the environment', EXS, vol. 101, no. 1, pp. 133-164, doi: 10.1007/978-3-7643-8340-4_6

Page $17 / 23$ 
69. Tippler C, Wright I, Hanlon A 2012, 'Is catchment imperviousness a keystone factor degrading urban waterways? A case study from a partly urbanised catchment (Georges River, South-Eastern Australia)', Water, Air and Soil Pollution, vol. 223, no. 8, pp. 5331-5344, doi: 10.1007/s11270-012-1283-5

70. Tippler C, Wright IA, Davies PJ, Hanlon A 2014, 'The influence of concrete on the geochemical qualities of urban streams', Marine and Freshwater Research, vol. 65, no. 11, pp. 1009-1017, doi: 10.1071/MF13164

71. Ugulu I (2015) 'Determination of heavy metal accumulation in plant samples by spectrometric techniques in Turkey'. Appl Spectrosc Rev 50(2):113-151. doi:10.1080/05704928.2014.935981

72. Walsh CJ, Roy AH, Feminella JW, Cottingham PD, Groffman PM, Morgan RP (2005) 'The urban stream syndrome: current knowledge and the search for a cure'. Journal of the North American Benthological Society 24(3):706-723. doi:10.1899/04-028.1

73. Wang A, Angle J, Chaney R, Delorme T, Reeves R 2006, 'Soil pH Effects on Uptake of Cd and Zn by Thlaspi caerulescens', Plant Soil, vol. 281, no. 1, pp. 325-337, doi: 10.1007/s11104-005-4642-9

74. Ward CR, French D, Jankowski J, Dubikova M, Li Z, Riley KW (2009) 'Element mobility from fresh and long-stored acidic fly ashes associated with an Australian power station'. International journal of coal geology 80(3):224-236. doi:10.1016/j.coal.2009.09.001

75. Webb AA, Erskine WD (2003) 'A practical scientific approach to riparian vegetation rehabilitation in Australia'. J Environ Manage 68(4):329-341. doi:10.1016/S0301-4797(03)00071-9

76. Wenger SJ, Roy AH, Jackson CR, Bernhardt ES, Carter TL, Filoso S, Gibson CA, Hession WC, Kaushal SS, Mart E, Meyer JL, Palmer MA, Paul MJ, Purcell AH, Ramrez A, Rosemond AD, Schofield KA, Sudduth EB, Walsh CJ (2009) 'Twenty-six key research questions in urban stream ecology: an assessment of the state of the science'. Journal of the North American Benthological Society 28(4):1080-1098. doi:10.1899/08-186.1

77. Wright I, Davies P, Findlay S, Jonasson O 2011, 'A new type of water pollution: concrete drainage infrastructure and geochemical contamination of urban waters', Marine and Freshwater Research, vol. 62, no. 12, pp. 1355-1361, doi: 10.1071/MF10296

78. Wright I, Khoury R, Ryan M, Belmer N, Reynolds J (2018) 'Laboratory study of impacts of concrete fragment sizes on wetland water chemistry'. Urban Water Journal 15(1):61-67. doi:10.1080/1573062X.2017.1395897

\section{Figures}



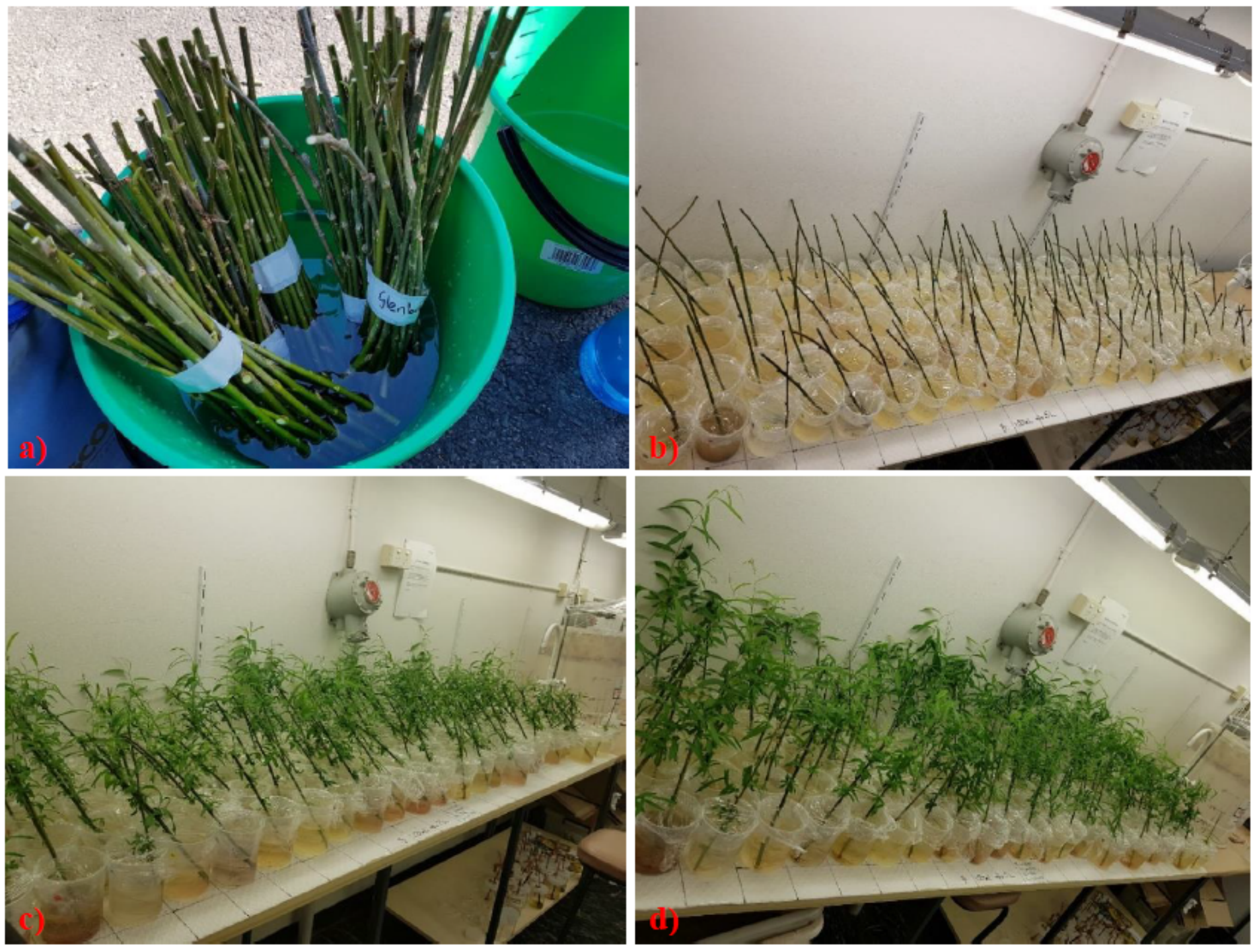

\section{Figure 1}

Willow branches a) when first collected, b) when first planted, c) at 3 weeks growth, and d) at 6 weeks growth (Katherine Purdy 2019). 


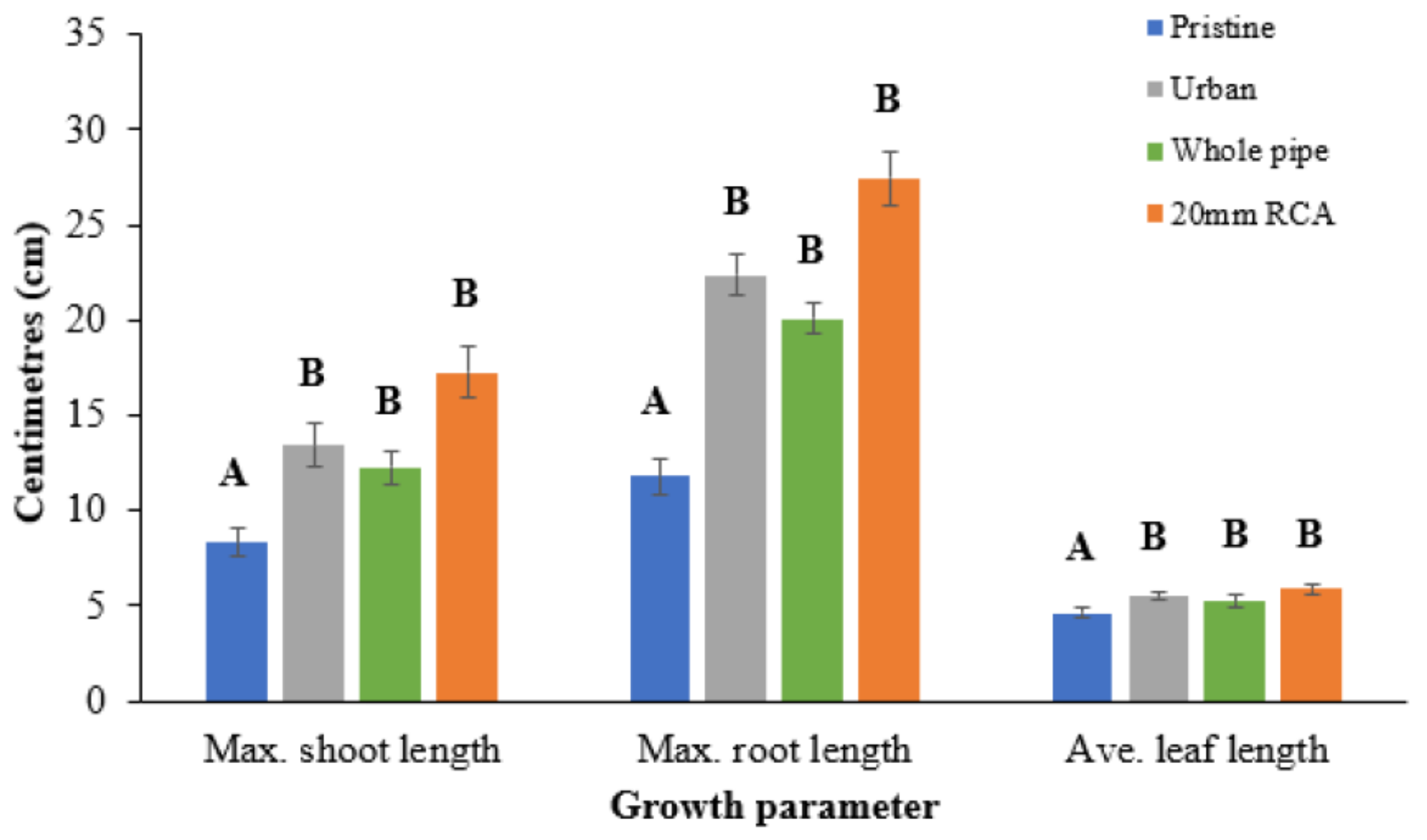

Figure 2

Mean $( \pm S E)$ of measured growth parameters for willow trees grown in each water type. Different colours indicate different water types, as shown in the figure legend. Different letters on top of bars indicate significant difference according to a Dunn's posthoc test $(\mathrm{p}<0.05)$. 


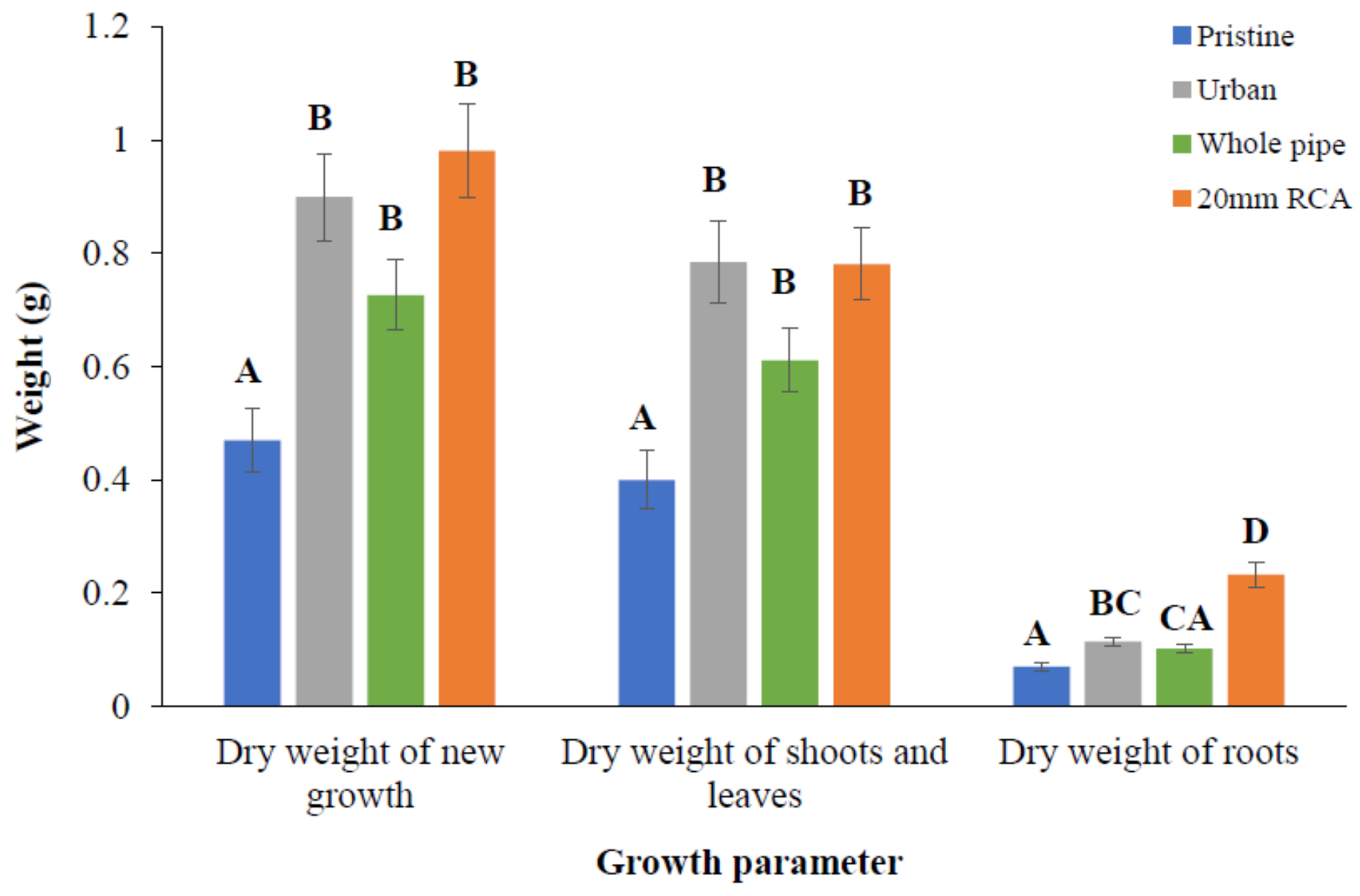

Figure 3

Mean ( \pm SE) of dry weights for willow trees grown in each water type. Different colours indicate different water types, as shown in the figure legend. Different letters on top of bars indicate significant difference according to a Dunn's posthoc test $(p<0.05)$. 

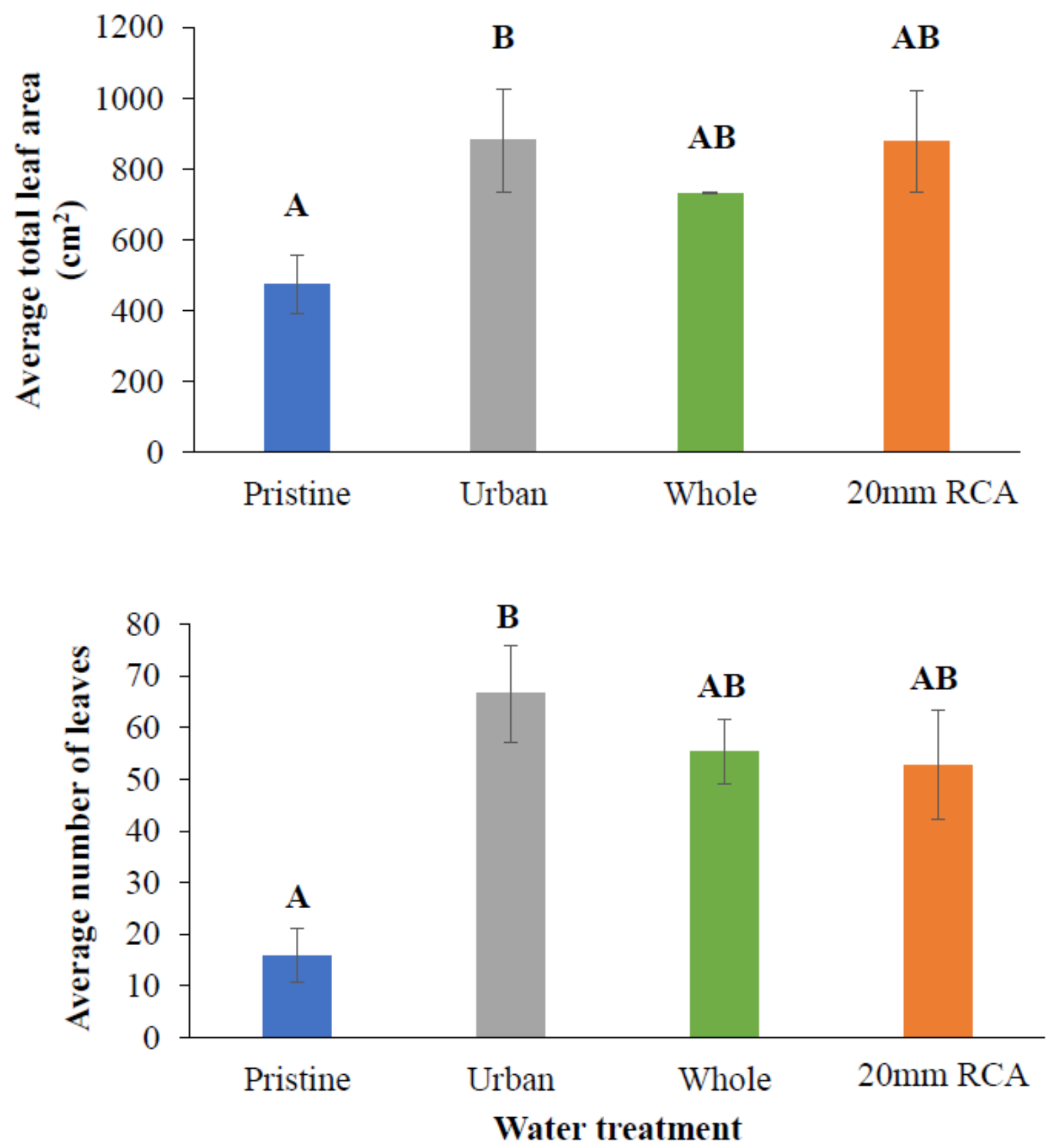

Figure 4

Mean ( \pm SE) total leaf area (top) and number of leaves (bottom) for willow tree cuttings grown in each water treatment. Different colours indicate different water types, as shown in the figure legend. Different letters on top of bars indicate significant difference according to a Dunn's posthoc test $(p<0.05)$ 


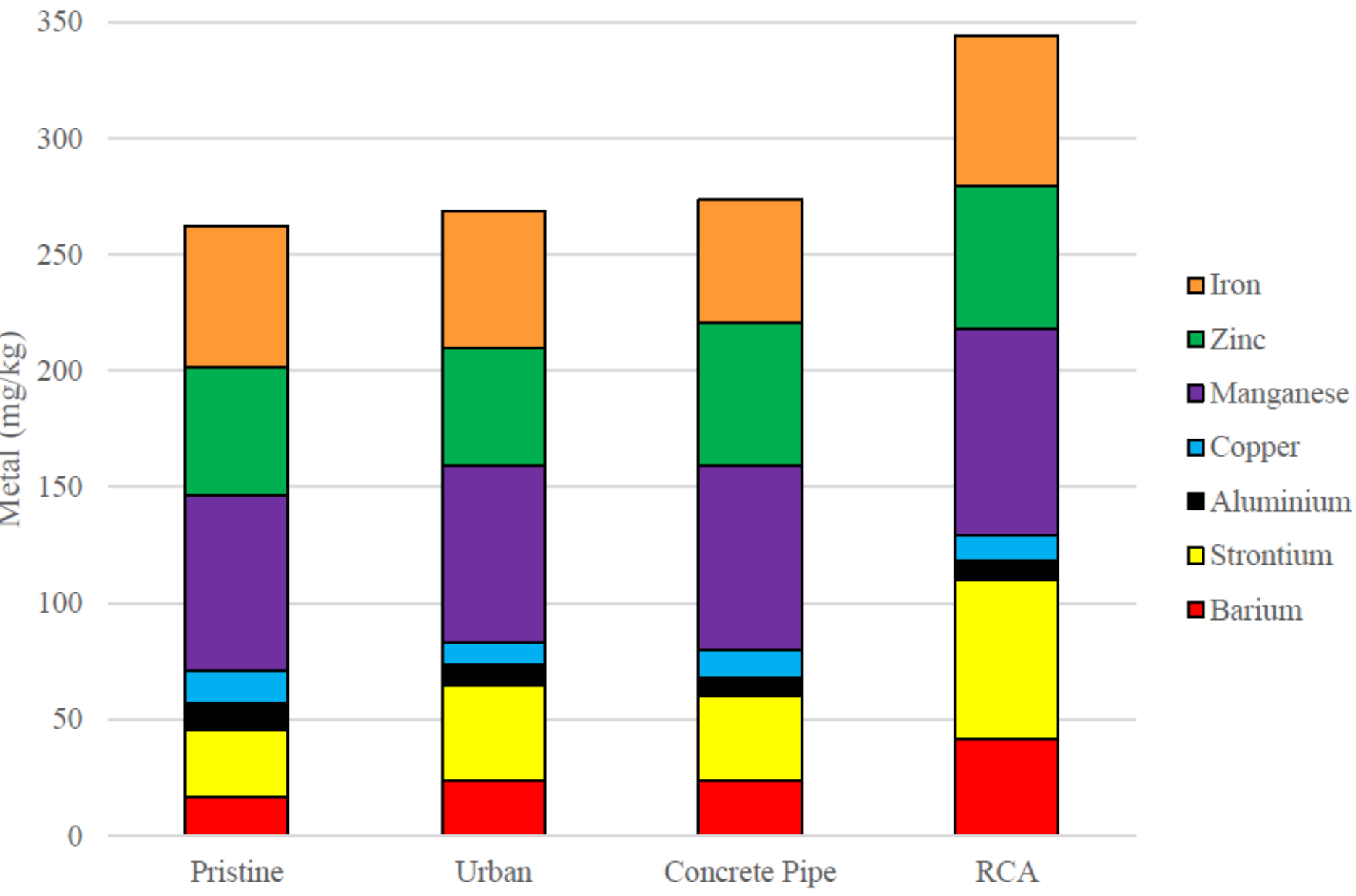

Figure 5

The mean metal content, for seven metals, measured in the dried tissue of willow cutting shoots that had been grown in the four different water treatments for 7.5 weeks. The legend displays each metal while the bars indicate the contribution of each metal. 